\title{
Metabolism of Parathyroid Hormone by Isolated Rat Kupffer Cells and Hepatocytes
}

\author{
Gino V. Segre, Archibald S. Perkins, Lee A. Witters, and \\ JoHN T. PotTs, JR., Endocrine and Diabetes Units, Department of Medicine, \\ Massachusetts General Hospital and Harvard Medical School, \\ Boston, Massachusetts 02114
}

\begin{abstract}
A B S T R A C T Data from several laboratories indicate that hepatic mechanisms may have a distinctive role in the metabolism of intact hormone after secretion, a process that accounts, at least partly, for the heterogeneity of circulating parathyroid hormone. Accordingly, we studied the proteolysis of intact hormone by isolated rat Kupffer cells and hepatocytes. Kupffer cells $\left(10^{6}\right.$ cells $\left./ \mathrm{ml}\right)$ and hepatocytes $\left(10^{7}\right.$ cells $\left./ \mathrm{ml}\right)$ were incubated with unlabeled and ${ }^{125} \mathrm{I}$-labeled bovine parathyroid hormone at $37^{\circ} \mathrm{C}$ for periods ranging up to $2 \mathrm{~h}$. When incubated with Kupffer cells, intact hormone disappeared with a $t_{1 / 2}$ of $12 \pm 4$ min. Radioimmunoassays using sequence-specific antisera showed that the dominant hormonal fragments recovered in the medium have an apparent molecular weight of $\sim 6,000$, lack amino-terminal antigenic determinants, and react in assays that specifically recognize determinants in the carboxy-terminal portion of the intact hormone. Amino-terminal fragments also were detected in high concentrations, particularly after short incubation periods. Radioiodinated fragments resulting from incubation of ${ }^{125}$ I-labeled bovine parathyroid hormone with Kupffer cells had the same apparent size as fragments derived from the metabolism of unlabeled, intact hormone; when analyzed by Edman degradation, positions 34 and 37 of the intact hormone sequence were the amino-terminal amino acids of these dominant carboxy-terminal fragments. Hepatocytes did not hydrolyze the hormone. Thus, metabolism of parathyroid hormone by Kupffer cells results in the appearance of fragments in the media
\end{abstract}

Dr. Segre and Dr. Witters are recipients of Research Career Development awards AM 00070 and 00520, respectively, from the National Institute of Arthritis, Metabolism, and Digestive Diseases.

This work was presented, in part, at the national meeting of the American Society for Clinical Investigation and was reported in abstract form in 1978. Clin. Res. 26: 533A.

Received for publication 14 February 1980 and in revised form 18 August 1980. that are immunochemically indistinguishable from, and chemically identical with, those found in plasma when intact hormone is injected intravenously. This indicates that the proteolysis observed in vitro accurately reflects the metabolism of the hormone in vivo. The detection of amino-terminal fragments in concentrations nearly equal to those of carboxyterminal fragments indicates that cleavage of intact hormone is, initially, by an endopeptidase(s).

Kupffer cells may be a source from which specific protease(s) that hydrolyze parathyroid hormone can be characterized, particularly in terms of enzymic specificity and requirements for inhibition. Detailed analysis of the cellular and molecular events during incubation of parathyroid hormone with these cells may help to clarify the biologic significance of the peripheral metabolism of the hormone.

\section{INTRODUCTION}

A recent review (1) and the accompanying report summarize the many lines of evidence that point to the paramount importance of the liver in the metabolism of parathyroid hormone (PTH). ${ }^{1}$ Extraction of intact bovine PTH (bPTH) by the liver is as great as or greater than that of any other organ, and the liver also releases $\mathrm{COOH}$-terminal fragments into the hepatic venous effluent both in vivo and in vitro. As we showed in the accompanying report, near-total hepatectomy results in the markedly delayed clearance of intact hormone from plasma and the virtual disappearance of $\mathrm{COOH}$-terminal fragments that characteristically appear in the circulation as a result of cleavage of intravenously injected intact hormone. These unique properties of the liver, particularly the liver's role in generating and releasing $\mathrm{COOH}$-terminal fragments

\footnotetext{
'Abbreviations used in this paper: bPTH, bovine parathyroid hormone; PTH, parathyroid hormone; KRB, KrebsRinger bicarbonate; MRCU, Medical Research Council Unit.
} 


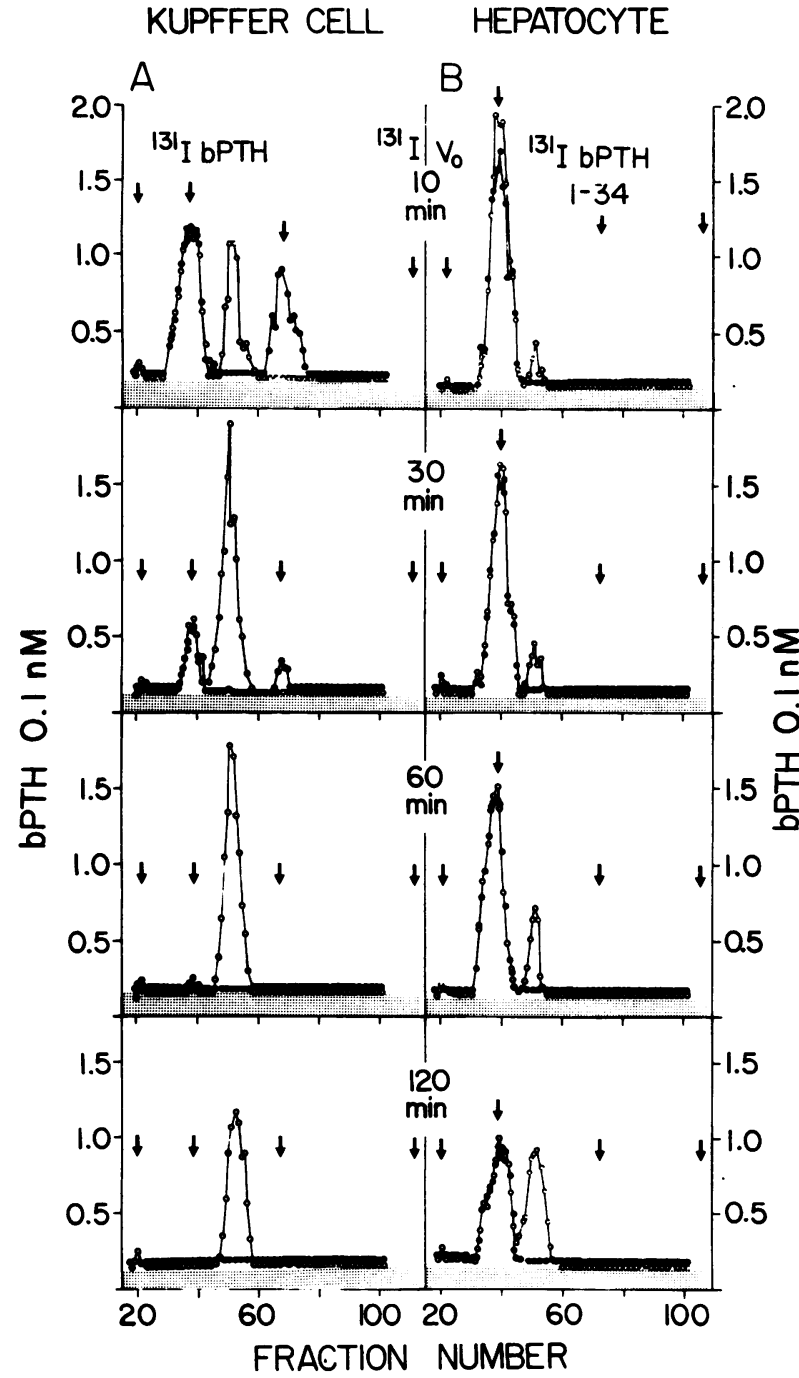

FIGURE 1 Immunoreactivity in fractions after gel filtration of media from incubation of intact bPTH with (A) Kupffer cells and (B) hepatocytes. Specific $\mathrm{NH}_{2}$-terminal $(O)$ and COOH-terminal $(O)$ immunoreactivity was measured by radioimmunoassay with GP-1 preincubated with excess bPTH(53-84) and bPTH-(1-34), respectively. The shaded area represents the detection limits of the radioimmunoassay. The elution position of fractions within the void volume $\left(\mathrm{V}_{0}\right)$ and the elution positions of bPTH-(1-84), bPTH-(1-34) and ${ }^{131} \mathrm{I}$ are indicated by the arrows. The data are representative of those obtained in three separate studies.

into the circulation, suggested that more detailed chemical examination of these proteolytic events at the cellular level would provide information physiologically relevant to the peripheral metabolism of PTH in the intact animal.

Although the work of Barrett et al. (2) indicated rapid metabolism of PTH by isolated hepatic cells, little is known about the specific cell types involved and the chemical details of the proteolytic events.
Our present studies, using unlabeled and ${ }^{125} \mathrm{I}-\mathrm{PTH}$, were undertaken principally to identify the hepaticcell type that contains the enzyme(s) responsible for the specific proteolysis of PTH.

\section{METHODS}

Preparation of bPTH and bPTH fragments. Intact bPTH and bPTH-(53-84), a product of tryptic digestion of highly purified native hormone after reversible blockade of $\epsilon$-amino groups of lysine residues, were prepared $(3,4)$. bPTH(1-34) was synthesized by solid-phase methods and purified (5). Biologic activity of bPTH-(1-84) was 3,000 MRCU/ $\mathrm{mg}$ in the in vitro rat renal cortical adenylate cyclase assay (6) and 2,500 MRCU/mg in the in vivo chick hypercalcemia assay (7).

bPTH-(1-84) and bPTH-(1-34) were iodinated with $\mathrm{Na}^{125} \mathrm{I}$ or $\mathrm{Na}^{131} \mathrm{I}$ (New England Nuclear, Boston, Mass.) by modification (8) of the method of Hunter and Greenwood (9). After iodination, hormonal preparations were purified, initially by adsorption to QUSO-G-32 (Philadelphia Quartz Co., Valley Forge, Pa.), and then gel filtered on Bio-Gel P-100 (Bio-Rad Laboratories, Richmond, Calif.) (10). Specific activity, estimated in samples of radiolabeled bPTH-(1-84) precipitated with $10 \%$ trichloroacetic acid, was $250 \pm 50$ $\mathrm{mCi} / \mathrm{mg}$.

Preparation of cell suspensions. Male Sprague-Dawley rats (CD-1, 150-200 g, Charles River Breeding Laboratories, Wilmington, Mass.) were fed ad lib. with standard rat chow. After they were anesthetized with intraperitoneal amobarbital $(0.2 \mathrm{mg} / \mathrm{g})$, a suspension $(0.6 \mathrm{ml})$ of colloidal iron $(0.3 \mathrm{~g} / \mathrm{ml})$ in $2.2 \mathrm{M}$ sucrose was slowly injected $(20 \mathrm{~s})$ into the exposed inferior vena cava. Colloidal iron, consisting of elementaliron particles, 3-4 $\mu \mathrm{m}$ (carbonyl iron, S-F Special, GAF Corp., New York), was homogenized in sucrose in an all glass apparatus immediately before use. Cell suspensions were prepared by a modification (11) of the method of Seglen (12); iron-laden cells (Kupffer cells) were separated from cells that did not phagocytize the iron by minor modifications of the method of Wincek et al. (13). After allowing $10 \mathrm{~min}$ for phagocytosis of the iron in vivo, the portal vein and the superior vena cava (above the diaphragm) were cannulated, the portal vein was ligated, and the abdominal vena cava was partly transected. Liver perfusion was begun in situ with $\mathrm{Ca}^{++}$-free Krebs-Ringer bicarbonate (KRB) buffer ( $\mathrm{pH} 7.4$, $37^{\circ} \mathrm{C}$ ) at a rate of $50-60 \mathrm{ml} / \mathrm{min}$. After perfusion with $300 \mathrm{ml}$ of buffer to free the liver of blood, the abdominal vena cava was ligated, and the liver was removed and placed in a recirculating perfusion system contained in a temperaturecontrolled hood maintained at $37^{\circ} \mathrm{C}$. The perfusate was then replaced by KRB ( $\mathrm{pH} 7.4$ ) containing $5 \mathrm{mM} \mathrm{Ca}^{++}, 5.5 \mathrm{mM}$ glucose, and $0.5 \mathrm{mg} / \mathrm{ml}$ collagenase (Type I, Lot CLS 45E059, Worthington Biochemical Corp., Freehold, N. J.) for $10 \mathrm{~min}$. The perfusate was oxygenated with a mixture of $95 \% \mathrm{O}_{2}$ and $5 \% \mathrm{CO}_{2}$ using a simple membrane oxygenator (14). After digestion, the liver was removed and gently teased apart into ice-cold $\mathrm{KRB}$ ( $\mathrm{pH} 7.4$ ) containing $1.3 \mathrm{mM}$ $\mathrm{Ca}^{++}$and $5.5 \mathrm{mM}$ glucose. The digest was collected in a polyethylene beaker $(125 \mathrm{ml})$ after filtration through a double layer of 100-mesh silk cloth. The beaker, containing the darkgray cell suspension, was placed in the core of a ceramic ring magnet and gently swirled for $1 \mathrm{~min}$. The iron-free cell suspension was gently decanted while the iron-laden cells remained attracted to the sides of the beaker. To rid the Kupffer cells of adherent hepatocytes and cell debris, the iron-laden cells were washed three times by gentle swirling with ice-cold KRB buffer and repeated magnetic separation. 
Microscopical examination revealed $<10 \%$ contamination of Kupffer cells by hepatocytes. The iron-free cell suspension was processed in a similar fashion. The suspension was gently washed three times with ice-cold KRB, and the remaining iron-laden cells and free colloidal iron were removed magnetically. Microscopical examination showed $<2 \%$ contamination of hepatocytes with iron-laden cells. The separated cell populations were then distributed in conical plastic tubes $(15 \mathrm{ml})$ and centrifuged for $2 \mathrm{~min}$ at $50 \mathrm{~g}$. The precipitated hepatocytes were gently washed two times by successive suspension and recentrifugation in ice-cold KRB buffer to free them of cell debris. The supernatant fluids were discarded. The pelleted Kupffer cells and hepatocytes were then gently suspended in Minimal Essential Medium (GIBCO, Grand Island Biological Company, Grand Island, N. Y.). containing $25 \mathrm{mM}$ Hepes buffer ( $\mathrm{pH} 7.4$ ), $10 \mathrm{mM}$ glucose, and $1.24 \mathrm{mM} \mathrm{Ca}^{++}$equilibrated with a mixture of $95 \% \mathrm{O}_{2}$ and $5 \% \mathrm{CO}_{2}$, distributed into polyethylene vessels, gassed with a mixture of $95 \% \mathrm{O}_{2}$ and $5 \% \mathrm{CO}_{2}$, and incubated at $37^{\circ} \mathrm{C}$ in an oscillating water bath (Lab-Line Instruments, Inc., Melrose Park, Ill.) at 60 cycle $/ \mathrm{min}$ for $30 \mathrm{~min}$. Preliminary cell counts were established with a clinical hemocytometer. The suspension then was refiltered through the silk cloth, the volume distributed in plastic conical tubes $(15 \mathrm{ml})$, and centrifuged at $50 \mathrm{~g}$ for $2 \mathrm{~min}$. The cells were harvested and resuspended in fresh incubation medium at $37^{\circ} \mathrm{C}$, supplemented with $0.2 \%$ heat-inactivated bovine serum albumin (Armour Pharmaceutical Co., Phoenix, Ariz.) to final hepatocyte and Kupffer-cell concentrations of $10^{7}$ and $10^{6}$ cells $/ \mathrm{ml}$, respectively. Cell preparations were evaluated by exclusion of trypan blue. Experiments were not initiated unless $>90 \%$ of the hepatocytes excluded the dye and were not considered valid unless $>80 \%$ of the hepatocytes excluded the dye at the end of the incubation. We, like Wincek et al. (13), found that $\sim 80 \%$ of the Kupffer cells were stained with trypan blue. Because Wincek et al. (13) were unable to detect proteolytic activity due to cytoplasmic enzymes in fresh Kupffer-cell suspensions, they suggested that staining by trypan blue was probably the result of continued phagocytosis of the dye, rather than disruption of the plasma membrane.

Incubations. Suspensions of hepatocytes and Kupffer cells $(2-4 \mathrm{ml})$ were distributed into polyethylene vessels, gassed with a mixture of $95 \% \mathrm{O}_{2}$ and $5 \% \mathrm{CO}_{2}$ and incubated in the oscillating $(60 \mathrm{cycle} / \mathrm{min})$ water bath at $37^{\circ} \mathrm{C}$. After $15 \mathrm{~min}$ was allowed for equilibration, unlabeled bPTH $(5-30 \mathrm{ng} / \mathrm{ml})$ or ${ }^{125} \mathrm{I}-\mathrm{bPTH}(\mathrm{l} \mathrm{ng} / \mathrm{ml})$ was added, and the samples were removed at intervals ranging from 0 to $120 \mathrm{~min}$. In experiments in which samples were to be analyzed by Edman degradation, ${ }^{125} \mathrm{I}$-bPTH $(6 \mathrm{ng} / \mathrm{ml})$ was used. At designated time intervals, samples $(0.2-1.0 \mathrm{ml})$ were removed from each incubation vessel and centrifuged at $0^{\circ} \mathrm{C}$ in the Brinkmann model 3200 Centrifuge (Brinkmann Instruments, Inc., Westbury, N. Y.) for $3 \mathrm{~min}$. Media were then aspirated. Both pellets and media were denatured in $6 \mathrm{M}$ guanidine- $\mathrm{HCl}$ (Heico Laboratories, Delaware Water Gap, Pa.), quick-frozen in acetone/dry ice (Airco Industrial Gases, Airco, Inc., Murray Hill, N. J.), and stored at $-70^{\circ} \mathrm{C}$ until analyzed. A portion of the medium from incubations with unlabeled hormone was quick-frozen and stored without addition of guanidine for radioimmunoassay. Incubation vessels were regassed with a mixture of $95 \% \mathrm{O}_{2}$ and $5 \% \mathrm{CO}_{2}$ after removal of each sample.

Metabolism of ${ }^{125} \mathrm{I}$-labeled and unlabeled bPTH also was assessed in media without added cells and in "conditioned media." The latter were prepared by incubation of Kupffer cells in media without added hormone for $120 \mathrm{~min}$ at $37^{\circ} \mathrm{C}$. After separation of the cells by centrifugation $(10,000 \mathrm{~g}, 15$ $\mathrm{min}$ ), the media were aspirated and transferred to new vessels. The vessels were regassed with a mixture of $95 \% \mathrm{O}_{2}$ and
$5 \% \mathrm{CO}_{2}$, and the hormonal preparations were incubated for 60 and $120 \mathrm{~min}$ at $37^{\circ} \mathrm{C}$.

Analytic methods. All samples, except those for sequence analyses, were initially gel filtered on columns $(1.2 \times 100 \mathrm{~cm})$ of Bio-Gel P-100 (100-200 mesh, Bio-Rad Laboratories, Richmond, Calif.) at $4^{\circ} \mathrm{C}$ with an eluting buffer of $0.05 \mathrm{M}$ sodium barbital: $10 \%$ (vol/vol) out-dated blood-bank plasma $\mathrm{pH}$ 8.6. Because the Edman reaction cannot be efficiently conducted in barbital buffer, samples for sequence analysis were lyophilized after gel filtration on columns $(1.2 \times 100 \mathrm{~cm})$ of Bio-Gel P-100 using $0.1 \mathrm{M}$ ammonium acetate: $1 \%$ (vol/ vol) blood-bank plasma, $\mathrm{pH}$ 5.0, as the eluting buffer. Intact ${ }^{131} \mathrm{I}-\mathrm{bPTH},{ }^{131} \mathrm{I}-\mathrm{bPTH}-(\mathrm{l}-34)$, and $\mathrm{Na}^{131} \mathrm{I}$, added to each sample immediately before gel filtration, served to calibrate the column. The amount of the ${ }^{131}$ I-labeled peptides added was insufficient to interfere with the radioimmunoassays. Fraction size was $0.9 \mathrm{ml}$. The ${ }^{125} \mathrm{I}$ in each fraction was counted in a dual-channel spectrometer (Packard Instrument Co., Inc., Downers Grove, Ill.) with appropriate correction of ${ }^{125} \mathrm{I}$ counts for ${ }^{131} \mathrm{I}$.

Automated Edman degradations were performed in a model 890 Sequencer (Beckman Instruments, Inc., Spinco Div. Palo Alto, Calif.) using a single-coupling, double-cleavage program (15). Lyophilized samples were dissolved in heptafluorobutyric acid. All procedures used for converting the anilinothiazolinone derivatives of the amino acids and for identifying the radioiodinated derivatives were previously reported $(10,16)$. All samples were degraded for at least 25 cycles. The results are expressed after correction for a repetitive yield of $93 \%$ for each cycle of the degradation; this figure represents the average yield found in eight degradations of myoglobin.

Radioimmunoassays that measure specific regions of the PTH sequence were performed, using antiserum GP-1 and nonequilibrium conditions as previously described $(8,17)$ Highly purified bPTH was used as the standard, and, after iodination with ${ }^{125} \mathrm{I}$, the same preparation was used as the tracer. GP-1 recognizes two major antigenic determinants in the bPTH molecule: one that includes some or all of the 14-27 region and one that includes some or all of the 53-84 region $(8,17)$. To restrict antigenic recognition to $\mathrm{NH}_{2}$ and $\mathrm{COOH}$-terminal regions of the molecule, respectively, assays using GP-1 were conducted after preincubating the antiserum with an excess of either bPTH-(53-84) or bPTH(1-34).

\section{RESULTS}

Incubations of bPTH with isolated hepatic cells. Samples were removed at $10,30,60$, and $120 \mathrm{~min}$ after addition of intact bPTH $(5-30 \mathrm{ng} / \mathrm{ml})$ to suspensions of isolated Kupffer cells or hepatocytes. Portions of unfractionated media and fractions eluting after gel filtration of the media were assayed in $\mathrm{NH}_{2-}$ and $\mathrm{COOH}$-terminal specific radioimmunoassays. After incubation of the intact hormone with Kupffer cells for $10 \mathrm{~min}$, the media contained $90 \pm 7 \%$ and $85 \pm 9 \%$ of the hormonal concentrations added initially to the incubation when measured in $\mathrm{COOH}-$ and $\mathrm{NH}_{2}$ terminal specific assays, respectively (Table I). After longer incubation periods, a striking discrepancy between the concentration of $\mathrm{NH}_{2^{-}}$and $\mathrm{COOH}$ terminal immunoreactivity became evident. After 60 and $120 \mathrm{~min}$, respectively, $80 \pm 10 \%$ and $53 \pm 18 \%$ of 
TABLE I

Immunoreactivity Recovered in the Media after Incubations of Intact bPTH with Kupffer Cells and Hepatocytes*

\begin{tabular}{cccccc}
\hline & \multicolumn{2}{c}{ Kupffer cells } & & \multicolumn{2}{c}{ Hepatocytes } \\
\cline { 2 - 3 } \cline { 5 - 6 } Time & $\mathrm{NH}_{2}$-terminal & COOH-terminal & & $\mathrm{NH}_{2}$-terminal & COOH-terminal \\
\hline $\min$ & \multicolumn{2}{c}{$10^{6}$ cells/ml $\$$} & & \multicolumn{2}{c}{$10^{7}$ cells/ml $\downarrow$} \\
10 & $85 \pm 9$ & $90 \pm 7$ & & $90 \pm 7$ & $94 \pm 6$ \\
30 & $60 \pm 10$ & $85 \pm 8$ & & $79 \pm 8$ & $88 \pm 11$ \\
60 & $20 \pm 11$ & $80 \pm 10$ & & $69 \pm 13$ & $85 \pm 14$ \\
120 & $8 \pm 7$ & $53 \pm 18$ & & $36 \pm 12$ & $60 \pm 20$ \\
\hline
\end{tabular}

* Expressed as a percentage of the immunoreactive, intact hormone present when the incubation was initiated. Values are the mean $\pm S E M$.

$\ddagger n=3$.

the $\mathrm{COOH}$-terminal immunoreactivity that had been added initially was detected, but only $20 \pm 11 \%$ and $8 \pm 7 \%$ of the $\mathrm{NH}_{2}$-terminal immunoreactivity remained after these incubation periods (Table I).

Radioimmunoassay of fractions derived from gel filtration of the media, collected after incubation of bPTH with Kupffer cells for varying time periods, confirms and extends these findings. After 10-min incubations, the fall in intact-hormone concentration is matched by nearly equal concentrations of $\mathrm{COOH}$ and $\mathrm{NH}_{2}$-terminal immunoreactive fragments (Fig. 1A). The $\mathrm{COOH}$-terminal immunoreactive fragments elute between ${ }^{131}$ I-bPTH-(1-84) and ${ }^{131}$ I-bPTH-(1-34), a position identical with that of the $\mathrm{COOH}$-terminal fragments found in plasma. The $\mathrm{NH}_{2}$-terminal immunoreactive fragments co-elute with ${ }^{131} \mathrm{I}-\mathrm{bPTH}-(1-34)$. After 120-min incubations, no intact hormone was detected in any experiment, and, in one study, none was present after $60 \mathrm{~min}$. Quantitation of the immunoreactivity detected in the position of intact hormone showed that, when incubated with Kupffer cells, intact bPTH disappears with an initial $t_{1 / 2}$ of $12 \pm 4 \mathrm{~min}$. The minimal loss of total immunoreactivity measured in unfractionated media during the first $10 \mathrm{~min}$ of incubation (Table I) appears to be because proteolysis of intact hormone yielded nearly equal concentrations of $\mathrm{COOH}$ - and $\mathrm{NH}_{2}$-terminal fragments. During the initial $30 \mathrm{~min}$, the concentration of COOH-terminal immunoreactive fragments increased, and thereafter decreased only slightly. In contrast, the concentration of $\mathrm{NH}_{2}$ terminal immunoreactive fragments decreased progressively after $10 \mathrm{~min}$ of incubation. The relative stability of the $\mathrm{COOH}$-terminal fragments contrasts sharply with the rapidly falling concentration of intact hormone and $\mathrm{NH}_{2}$-terminal fragments, and accounts for the different disappearance rates of $\mathrm{COOH}$ - and $\mathrm{NH}_{2}$-terminal immunoreactivity detected in unfractionated media (Table I).

In comparison, the metabolism of intact hormone by hepatocyte suspensions $\left(10^{7}\right.$ cells $\left./ \mathrm{ml}\right)$ was much slower, although 10-fold higher cell concentrations were used. Measurements of immunoreactivity in unfractionated media showed that after incubation for 60 and $120 \mathrm{~min}, 85 \pm 14$ and $60 \pm 20 \%$, respectively, of the concentration of hormone added initially were detected by the $\mathrm{COOH}$-terminal assay, and $60 \pm 13$ and $36 \pm 12 \%$, respectively, by the $\mathrm{NH}_{2}$-terminal assay (Table I). Analysis of fractions after gel chromatography showed that, after 60 and $120 \mathrm{~min}$, respectively, $70 \pm 15$ and $32 \pm 18 \%$ of the hormone added initially remained intact, as assessed by their elution positions, results consistent with a $t_{1 / 2}$ of $\sim 80$ min (Fig. 1B). Low concentrations of $\mathrm{COOH}$-terminal fragments, but no $\mathrm{NH}_{2}$-terminal fragments were found. Failure to detect $\mathrm{NH}_{2}$-terminal fragments is presumably because of the slow rate of intact hormone cleavage, coupled with relatively more rapid proteolysis of the $\mathrm{NH}_{2}$ terminal fragments that were generated. These findings would be predicted from the low concentrations of Kupffer cells present in these incubations. Recovery of both $\mathrm{NH}_{2^{-}}$and $\mathrm{COOH}$-terminal immunoreactivity after gel chromatography ranged from 74 to $96 \%$.

Incubations of ${ }^{125}$ I-bPTH with isolated hepatic cells. To permit precise chemical identification of the products of proteolysis of bPTH and a more accurate assessment of the partitioning of hormone and its fragments between cells and media, ${ }^{125}$ I-bPTH was incubated with suspensions of isolated Kupffer cells and hepatocytes. Media and material recovered by extracting Kupffer cells and hepatocyte pellets with guanidine- $\mathrm{HCl}$ were chromatographed. With increasing incubation time with Kupffer cells, progressively increasing concentrations of ${ }^{125} \mathrm{I}$-labeled hormonal fragments were detected in the media. These fragments accounted for $55 \pm 15 \%$ of the radioactivity after $120 \mathrm{~min}$, and they eluted at the same column volume as the immunoreactive $\mathrm{COOH}$-terminal fragments. In addition, radioactivity eluting at the salt volume also increased with time and accounted for $20 \pm 10 \%$ of the ${ }^{125} \mathrm{I}$ after $120 \mathrm{~min}$ (Fig. 2A).

The media recovered after 60 -min incubations with Kupffer cells were initially gel filtered, and fractions from the region of the gel profile comprising the peak of late-eluting, ${ }^{125}$ I-labeled COOH-terminal fragments were pooled, lyophilized, and degraded by the automated Edman reaction. Fig. 3, which is representative of four experiments, shows the release of specific mono- and di-iodotyrosyl radioactivity principally at cycles 10 and 7 of the degradation. Inasmuch as the single tyrosyl residue in bPTH is located at position 43 in the intact sequence, recovery of iodotyrosyl radioactivity at these cycles is consistent with hormonal proteolysis between positions 33 and 34, and 36 and 37 of the intact sequence. Less prominent increases in release of radioactivity above background occurred at 


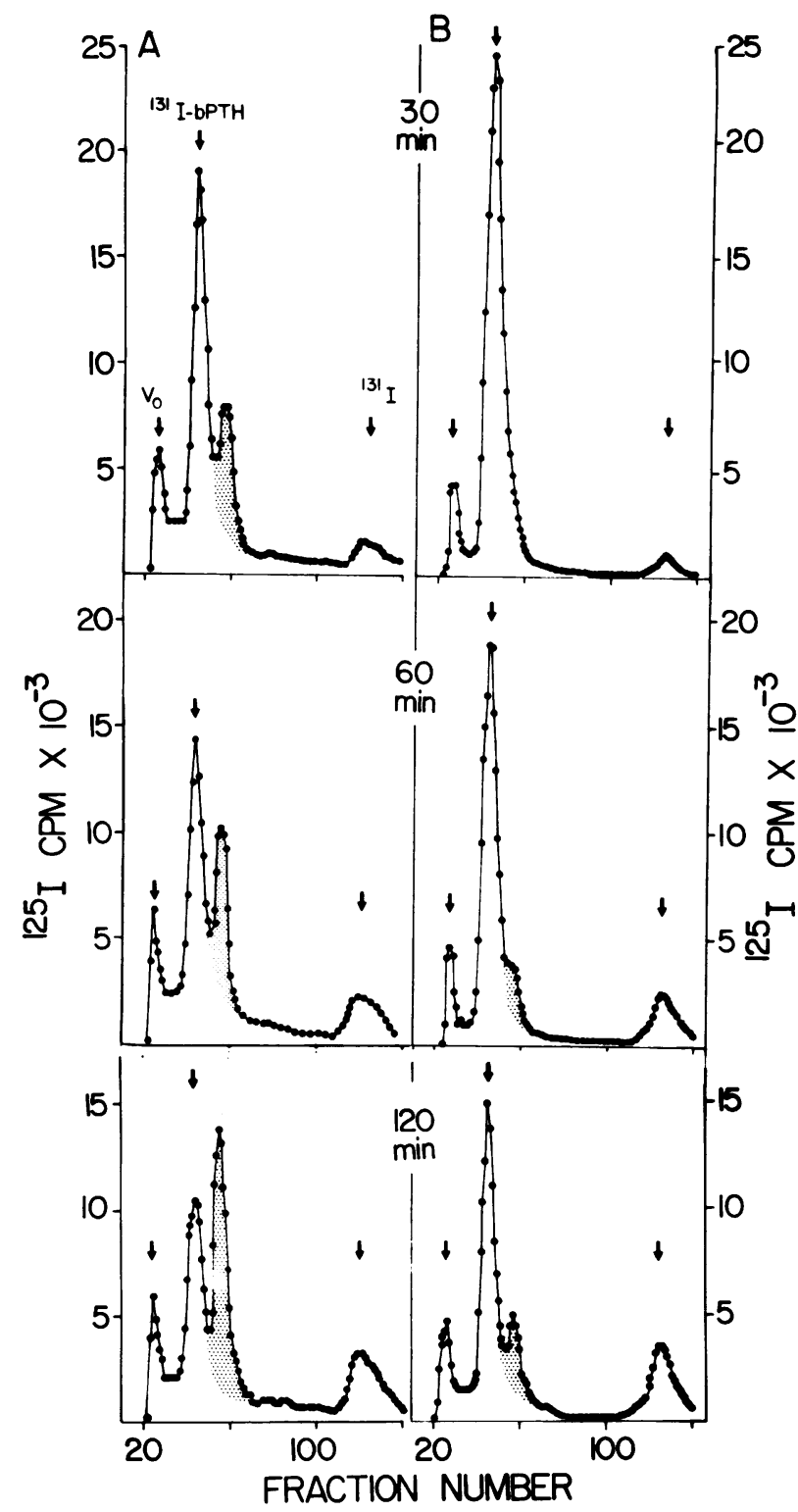

FIGURE $2{ }^{125} \mathrm{I}$ in fractions after gel filtration of media from incubations of ${ }^{125} \mathrm{I}-\mathrm{bPTH}$ with (A) Kupffer cells and (B) hepatocytes. The columns were calibrated as in Fig. 1. The shaded area represents the ${ }^{125}$ I-labeled hormonal fragments. The data are representative of those obtained in three separate studies.

cycle 3 , representing cleavage between positions 40 and 41 of the intact sequence. In all experiments, release of iodotyrosyl radioactivity, above background, also occurred after the first cycle of degradation, representing cleavage between positions 42 and 43 . The amount released was variable, but was consistently less than the amount detected at cycle 3 .

Fig. 2B shows that when ${ }^{125} \mathrm{I}-\mathrm{bPTH}$ was incubated with hepatocyte suspensions $\left(10^{7} \mathrm{cell} / \mathrm{ml}\right)$, relatively

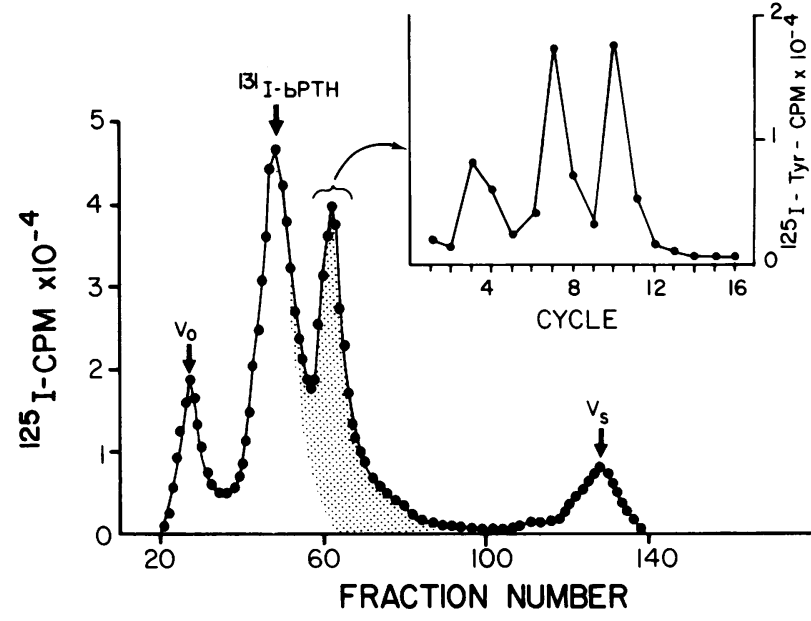

FIGURE $3 \quad{ }^{125}$ I in fractions after gel filtration of media isolated after incubation of ${ }^{125} \mathrm{I}$-bPTH with Kupffer cells for $60 \mathrm{~min}$ is shown at the lower left. The column was calibrated as in Fig. 1. The shaded area represents the ${ }^{125}$ I-labeled hormonal fragments. This region of the gel profile was pooled, and a portion was subjected to Edman degradation. Specific iodotyrosyl radioactivity released at each cycle of degradation is shown at the upper right. The data are representative of those obtained in four separate studies.

little metabolism of the intact hormone occurred. After 30 min, no COOH-terminal fragments were seen in two experiments, and only a minor, late-eluting shoulder of the intact-hormone peak was seen in one. Chromatography of the media recovered after 60 and $120 \mathrm{~min}$ of incubation showed that ${ }^{125}$ I-labeled hormonal fragments constituted $7 \pm 3 \%$ and $15 \pm 7 \%$ of the radioactivity. At these times, ${ }^{125} \mathrm{I}$ eluting at the salt volume was approximately equal in concentration to that of $\mathrm{COOH}$-terminal fragments.

The media recovered after 60 -min incubations with hepatocytes were also analyzed by sequence analysis. After the samples were gel filtered, fractions eluting from the region of the chromatogram that included a portion of the intact hormone peak and the small, late-eluting, ${ }^{125}$ I-labeled fragments were pooled, lyophilized, and degraded for 25 cycles. Quantitatively, the radioactivity released was far less than that seen when media from Kupffer cells were analyzed, but the pattern of iodotyrosyl radioactivity detected was identical. In both experiments, ${ }^{125}$ I was released principally at cycle 10 and 7 ; release of radioactivity above background also occurred at cycle 3 (figure not shown).

Extracts of Kupffer-cell pellets recovered between 30 and 120 min all contained $15 \pm 5 \%$ of the radioactivity added to the incubation. Gel filtration revealed that these cell pellets contained ${ }^{125}$ I that eluted primarily at a volume consistent with intact hormone and also contained a small amount of both ${ }^{125}$ I-labeled hormonal 


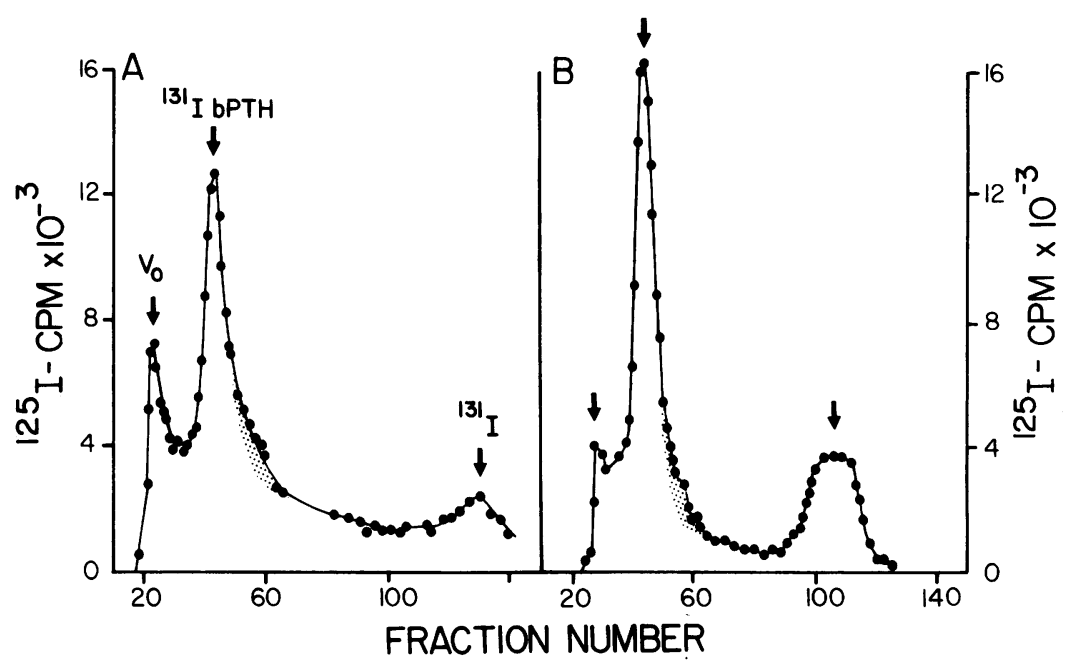

FIGURE $4{ }^{125} \mathrm{I}$ in fractions after gel filtration of extracts recovered from cell pellets after incubation of ${ }^{125}$ I-bPTH for 60 min with (A) Kupffer cells and (B) hepatocytes. Cell pellets were extracted with $6 \mathrm{M}$ guanidine- $\mathrm{HCl}$. The columns were calibrated as in Fig. 1 . The shaded area represents the ${ }^{125}$ I-labeled hormonal fragments. The data are representative of those obtained in three separate studies.

fragments and ${ }^{125} \mathrm{I}$ that eluted at the salt volume (Fig. 4A). The amount of ${ }^{125} \mathrm{I}$ in the hepatocyte pellets was approximately the same as that in the Kupffer-cell pellets, and, upon gel chromatography, the radioactivity also appeared to primarily elute at the position of intact hormone (Fig. 4B).

In each experiment, control incubations of ${ }^{125} \mathrm{I}-\mathrm{bPTH}$ with media alone for $120 \mathrm{~min}$ did not result in the appearance of any hormonal fragments.

Incubations of ${ }^{125}$ I-labeled and unlabeled bPTH with conditioned media. Media recovered after incubations of the hormone with conditioned media were compared with media from incubations of the hormone with Kupffer cells $\left(10^{6}\right.$ cells $\left./ \mathrm{ml}\right)$ for the same time intervals. After gel filtration of the samples, fractions were either immunoassayed or counted for radioactivity. In two experiments with intact, unlabeled bPTH and in three experiments with ${ }^{125}$ I-labeled hormone, hormonal fragments constituted an amount that was between 3 and 15\% of the amount seen when hormone was incubated in the presence of Kupffer cells for $60 \mathrm{~min}$ and $120 \mathrm{~min}$. However, in a fourth study that appeared successful by the usual criteria, the amount of ${ }^{125}$ I-labeled fragments detected in the conditioned media after 120 min was $55 \%$ of that detected in the incubation containing cells.

\section{DISCUSSION}

The present studies are based on our observations and those of others (for review, see [1] and accompanying report) that the liver in vivo is critical in the proteolytic metabolism of PTH, once this hormone enters the cir- culation. The reason for searching for the hepatic cell type responsible for hormonal proteolysis derives, in part, from our finding that the characteristic metabolic fate of injected, intact bPTH is radically altered in hepatectomized rats; the concentration of $\mathrm{COOH}$ terminal fragments, in plasma, is very low in these animals, and no radioiodinated $\mathrm{COOH}$ fragments with $\mathrm{NH}_{2}$-terminal residues at position 34 or 37 could be detected in their circulation. If cells containing these specific enzymes could be identified, then characterization and, perhaps, isolation of the enzyme(s) involved would be greatly facilitated. In addition, an in vitro test system would be very useful in evaluating potential competitive antagonists of the cleavage process, compounds that could serve as probes to study the biologic significance of the peripheral metabolism of the hormone in vivo.

We believe that the studies reported in these two companion manuscripts represent considerable progress in the understanding of the peripheral metabolism of PTH. Studies of the proteolysis of PTH by Kupffer cells now can be pursued with considerable assurance that they are physiologically relevant to the process of hormonal metabolism in vivo, because cleavage of the hormone by these cells in vitro is chemically identical with the pattern of cleavage seen when labeled hormone is injected into the intact animal.

By separating hepatic cell types, we showed that Kupffer cells, rather than hepatocytes, contain enzymes that are responsible for proteolysis of PTH. Concentrations of hepatocytes that are 10-fold greater than those of Kupffer cells hydrolyze PTH so slowly 
that the proteolytic activity seen in incubations with hepatocytes can be accounted for quantitatively by the presence of contaminating Kupffer cells.

Many issues remain unresolved, however, concerning the details of the metabolism of PTH in vitro and in vivo, as well as questions relating to the limitations of the methods used in these studies. For example, it is not known whether addition of a prosthetic group, ${ }^{125} \mathrm{I}$, to bPTH, or any other chemical modification of the hormone during the labeling procedure alters the properties of bPTH sufficiently to change either the rate or specificity of the enzymic attack on the molecule. Since Edman degradation cannot be performed on hormonal fragments of unlabeled bPTH in plasma, we lack the analytic methods to chemically define the precise sites of cleavage of unlabeled intact hormone. Thus, we have deduced, but not proved, that Kupffer cells cleave unlabeled intact hormone and ${ }^{125} \mathrm{I}-\mathrm{bPTH}$ in the same manner. Immunochemical studies using unlabeled hormone confirm the results seen with radioiodinated hormone within the limitations of the methods employed. Radioimmunoassays using sequence-specific antisera show that the dominant PTH fragments recovered in the media of Kupffercell incubations have an apparent molecular weight of $\sim 6,000$, lack $\mathrm{NH}_{2}$-terminal antigenic determinants, and react in radioimmunoassays that are specific for the COOH-terminal portions of the intact hormone sequence. The fragments in these media are immunochemically indistinguishable from, and chemically identical with, those found in plasma when unlabeled and ${ }^{125}$ I-labeled bPTH are injected intravenously in rats (10) and dogs (16). Most likely, the chemical properties of the metabolites of biologically active, intact hormone can be best defined by studying the proteolysis of biosynthetically prepared hormone that is labeled to high specific activity by incorporation of radioactive amino acids into the peptide sequence. However, the use of the radioiodinated probe has allowed us to validate our observations as we have proceeded from determinations of the fragments found in the circulation $(10,16)$ to those found in the liver $(18)$ to, currently, those generated by the Kupffer cells.

Our data seem to indicate that Kupffer cells metabolize unlabeled PTH faster than they metabolize the labeled hormone. Although we cannot dismiss the possibility that the different rates of proteolysis reflect intrinsic differences in the two substrates, these discrepancies in cleavage rates are more apparent than real. When tracer amounts of ${ }^{125}$ I-bPTH are chromatographed on columns with nondenaturing buffers in the presence of carriers, particularly plasma, a significant portion of the radioactivity elutes at the void volume of the column. Studies in intact animals showed that this form of ${ }^{125}$ I-labeled hormone appears to be metabolized much more slowly than the hormone that elutes at the appropriate column volume $(10,16,19)$. The fraction of ${ }^{125}$ I-labeled hormone eluting at the void volume is apparently protein-bound, thus accounting for its persistence in the circulation. Sequence analysis of radioactive hormone eluting at the void volume of the column showed both in our earlier (16) and in these current studies that this radioactive material is intact hormone rather than fragments. Thus, this "large" form of ${ }^{125} \mathrm{I}-\mathrm{bPTH}$ appears to be relatively unavailable for proteolytic attack. In contrast, analysis by radioimmunoassay of fractions after gel filtration of unlabeled intact PTH indicates that only a small portion of hormone elutes at the void volume $(16,20)$. The rates of metabolism of unlabeled and ${ }^{125}$ I-labeled hormone were shown to be the same in vivo only when the data were based on analysis of the fate of labeled and unlabeled hormone that elutes at the position of intact hormone after gel filtration with nondenaturing buffers (20).

In the current studies, highest priority was given to precise chemical identification of the fragments resulting from metabolism of ${ }^{125} \mathrm{I}-\mathrm{bPTH}$. As a preventive measure, therefore, samples were denatured with $6 \mathrm{M}$ guanidine- $\mathrm{HCl}$ to preclude potential proteolysis during further processing. Subsequent gel filtration revealed little radioactivity in the void volume of the column, reflecting the effectiveness of guanidine in dissociating the ${ }^{125} \mathrm{I}-\mathrm{bPTH}$ attached noncovalently to the protein carrier. Chromatography in the presence of denaturing solvents, such as guanidine- $\mathrm{HCl}$, seems most appropriate to protect against potential proteolysis during collection and storage of the samples, but it appears to artefactually distort the apparent rate of cleavage of the radiolabeled hormone when compared with unlabeled bPTH. We conclude, therefore, that the kinetics of PTH metabolism are best assessed from the studies of unlabeled hormone, whereas precise chemical identification of the hormone fragments requires studies with ${ }^{125}$ I-bPTH.

Certain problems also are associated with the techniques required to isolate the Kupffer cells. When bPTH is incubated with different aliquots of the same preparation of Kupffer cells, proteolysis is rapid and occurs at the same rate. However, the absolute rate of cleavage by the same number of cells varied (Table I), and appeared to depend on the specific cell preparation. The complex harvesting procedure required to collect Kupffer cells probably accounts for this variability and also for our observation that appreciable concentrations of fragments were detected in one of six incubations with conditioned media. We are exploring alternative techniques for preparing cell populations that have more stable and reproducible properties. If suitable methods can be found, the study of factors that influence PTH metabolism will be expedited.

Our findings do not necessarily imply that macro- 
phages other than Kupffer cells lack the enzymic complement to metabolize PTH. The position of Kupffer cells within hepatic sinusoids, the high fractional hepatic blood flow, and the relative abundance of macrophages in the liver might account, quantitatively, for the predominant role of these cells in the metabolism of the hormone. Whether macrophages from other sources also metabolize PTH is under study.

In addition to identifying the importance of Kupffer cells in the cleavage of PTH, these studies provide additional insights concerning the properties of the enzyme(s) involved and their location within the cell. In contrast to our results from studies of PTH metabolism in vivo, $\mathrm{NH}_{2}$-terminal fragments with an apparent molecular size similar to that of bPTH-(1-34) were consistently seen in these studies in vitro. We did not detect significant concentrations of circulating $\mathrm{NH}_{2}$ terminal fragments during analysis of hormonal metabolism in vivo $(8,16,20)$, and other laboratories have reported that, in plasma, the concentrations of $\mathrm{NH}_{2}-$ terminal fragments are much lower than are those of COOH-terminal fragments (21-24). This has led to uncertainty about the nature of the enzymic process. However, our data in vitro show that the initial attack on intact PTH is by an endopeptidase(s) that generates both $\mathrm{NH}_{2^{-}}$and $\mathrm{COOH}$-terminal fragments, rather than by an exopeptidase(s) that rapidly digests the $\mathrm{NH}_{2}$-terminal portion of the molecule. $\mathrm{NH}_{2}$-terminal fragments disappear from the medium within the first hour of incubation, at least as assessed by serial radioimmunoassays. The present data do not establish whether this represents rapid proteolysis to very small peptides by endopeptidases or exopeptidases, or relatively small chemical changes in these fragments that greatly reduce their immunoreactivity or uptake by the Kupffer cells. Nonetheless, our findings are consistent with results obtained in vivo that showed high concentrations of $\mathrm{COOH}$-terminal fragments but either failed to detect any $(8,16,20)$, or detected only very low concentrations (21-24) of $\mathrm{NH}_{2}$-terminal fragments in plasma; the much higher concentrations of $\mathrm{COOH}$ terminal fragments in comparison with concentrations of $\mathrm{NH}_{2}$-terminal fragments in this in vitro system are similar to the findings in vivo.

The location of the specific enzyme(s) involved in the proteolysis of PTH has not been precisely defined. The limited degradation of PTH in conditioned media indicates that the enzyme(s) involved probably are not secreted by the Kupffer cells, and the rapid rate with which intact PTH is hydrolyzed by Kupffer-cell suspensions suggests that, most likely, the protease activity is associated with cell surface. We have not excluded the possibility that the hormone may undergo intracellular metabolism accompanied by the rapid release of fragments into the extracellular space. However, the finding that the amount of ${ }^{125} I$ in the Kupffer- cell pellets was relatively small and that most of the ${ }^{125}$ I in these cells appeared to be associated with intact hormone (Fig. 4A) argues against a major role for endocytosis and lysosomal degradation in this process. Our data are compatible with the results of D'Amour et al. (25) that showed fragments in the hepatic venous effluent after a single pass of the hormone through the liver, and are consistent with, but do not prove, the idea that proteolysis of PTH may be a cell-surface phenomenon.

Recently, MacGregor et al. (26) isolated an enzyme from homogenates of porcine liver that hydrolyzed bPTH in a manner similar to, but apparently not identical with, that observed with Kupffer cells. This enzyme, which was purified to homogeneity from the supernatant fraction of liver homogenates, cleaves between positions 36 and 37 of intact bPTH and has characteristics that are consistent with the known properties of cathepsin B. Cathepsin B is generally considered to be an intracellular acid hydrolase that is in highest concentration within the lysosomes and is unstable at $\mathrm{pH} 7.0$ or above (27). It is not clear whether this enzyme is involved in the proteolysis of PTH by Kupffer cells. However, it has distinctive properties that may possibly have considerable relevance; it is the only enzyme thus far reported that hydrolyzes PTH at sites consistent with those that are cleaved in vivo.

Hepatic metabolism of PTH by the isolated, perfused rat liver was shown to release biologically active, $\mathbf{N H}_{2}$ terminal fragments into the perfusate (28). Therefore, it is attractive to speculate that an endopeptidase(s) in Kupffer cells may generate biologically active fragments that may act locally in the liver or have preferential effects on particular target tissues. Alternatively, hormonal cleavage may be merely a catabolic process leading to inactivation of the hormone through destruction of $\mathrm{NH}_{2}$-terminal portion of the sequence. This possibility is suggested by the finding that $\mathrm{NH}_{2}-$ terminal fragments rapidly disappear in vitro and are not detected in substantial concentrations in plasma in vivo.

Our studies of the metabolism of PTH by hepatectomized rats in vivo and by Kupffer cells in vitro indicate that detailed physiological and biochemical studies with Kupffer cells should provide further insight into some of the issues involving the complex metabolism of this hormone and the relationship between proteolysis of the hormone and its biologic actions. Studies in vitro using these cells also may be applied to the design of analogues that are more potent inhibitors of hormonal proteolysis than is bPTH(28-48), a compound that effectively inhibits cleavage of PTH, but only at high concentration (29). Potent inhibitors in vitro also may prove, upon subsequent testing, to be effective inhibitors in vivo and may be 
useful in studies to clarify the biological significance of the peripheral metabolism of the hormone.

\section{ACKNOWLEDGMENTS}

We thank Ms. Anne Hultman and Mr. James Laugharn for technical assistance. This work was supported in part by AM 11794,04501 , and 19270 from the National Institute of Arthritis, Metabolism, and Digestive Diseases and by contract NAS 9-11011 from the National Aeronautics and Space Administration.

\section{REFERENCES}

1. Martin, K. J., K. A. Hruska, J. J. Freitag, S. Klahr, and E. Slatopolsky. 1979. The peripheral metabolism of parathyroid hormone. N. Engl. J. Med. 301: 1092-1098.

2. Barrett, P. Q., A. Teitelbaum, W. F. Neuman, and M. W. Neuman. 1978. The role of the liver in the peripheral metabolism of parathyroid hormone. In Endocrinology of Calcium Metabolism, Proceedings. 6th Parathyroid conference, Vancouver. D. H. Copp and R. V. Talmage, editors. Excerpta Medica, Amsterdam. 324-328.

3. Keutmann, H. T., G. D. Aurbach, B. F. Dawson, H. D. Niall, L. J. Deftos, and J. T. Potts, Jr. 1971. Isolation and characterization of the bovine parathyroid isohormones. Biochemistry. 10: 2779-2787.

4. Sauer, R. T., H. D. Niall, M. L. Hogan, H. T. Keutmann, J. L. H. O'Riordan, and J. T. Potts, Jr. 1974. The amino acid sequence of porcine parathyroid hormone. Biochemistry. 13: 1994-1999.

5. Tregear, G. W., J. van Rietschoten, E. Greene, H. T. Keutmann, H. D. Niall, B. Reit, J. A. Parsons, and J. T. Potts, Jr. 1973. Bovine parathyroid hormone: minimum chain length of synthetic peptide required for biological activity. Endocrinology. 93: 1349-1353.

6. Marcus, R., and G. D. Aurbach. 1969. Bioassay of parathyroid hormone in vitro with a stable preparation of adenyl cyclase from rat kidney. Endocrinology. 85: 801-810.

7. Parsons, J. A., B. Reit, and C. J. Robinson. 1973. A bioassay for parathyroid hormone using chicks. Endocrinology. 92: 454-462.

8. Segre, G. V., J. F. Habener, D. Powell, G. W. Tregear, and J. T. Potts, Jr. 1972. Parathyroid hormone in human plasma: immunochemical characterization and biological implications. J. Clin. Invest. 51: 3163-3672.

9. Hunter, W. M., and F. C. Greenwood. 1962. Preparation of iodine-131 labelled human growth hormone of high specific activity. Nature (Lond.). 194: 495-496.

10. Segre, G. V., P. D'Amour, and J. T. Potts, Jr. 1976. Metabolism of radio-iodinated bovine parathyroid hormone in the rat. Endocrinology. 99: 1645-1652.

11. Witters, L. A., L. Alberico, and J. Avruch. 1976. Insulin regulation of glycogen synthase in the isolated rat hepatocyte. Biochem. Biophys. Res. Commun. 69: 997-1003.

12. Seglen, P. O. 1973. Preparation of rat liver cells. III. Enzymatic requirements for tissue dispersion. Exp. Cell Res. 82: 391-398.

13. Wincek, T. J., A. L. Hupka, and F. W. Sweat. 1975. Stimulation of adenylate cyclase from isolated hepatocytes and Kupffer cells. J. Biol. Chem. 250: 8863-8873.

14. Hamilton, R. L., M. N. Berry, M. C. Williams, and E. M.
Severinghaus. 1974. A simple and inexpensive membrane "lung" for small organ perfusion. J. Lipid Res. 15: $182-186$.

15. Edman, P., and E. Begg. 1967. A protein sequenator. Eur. J. Biochem. 1: 80-91.

16. Segre, G. V., H. D. Niall, R. T. Sauer, and J. T. Potts, Jr. 1977. Edman degradation of radioiodinated parathyroid hormone: application of sequence analysis and hormone metabolism in vivo. Biochemistry. 16: 2417-2427.

17. Segre, G. V., G. W. Tregear, and J. T. Potts, Jr. 1975. Development and application of sequence-specific radioimmunoassays for analysis of the metabolism of parathyroid hormone. Methods Enzymol. 37: 38-66.

18. D'Amour, P., G. V. Segre, S. I. Roth, and J. T. Potts, Jr. 1979. Analysis of parathyroid hormone and its fragments in rat tissues: chemical identification and microscopical localization. J. Clin. Invest. 63: 89-98.

19. Barrett, P. Q., A. P. Teitelbaum, and W. F. Neuman. 1978. The heterogeneity of radioiodinated parathyroid hormone in rat plasma. Metab. Bone Dis. Rel. Res. 1: 263-267.

20. Segre, G. V., H. D. Niall, J. F. Habener, and J. T. Potts, Jr. 1974. Metabolism of parathyroid hormone: physiological and clinical significance. Am. J. Med. 56: 774-784.

21. Canterbury, J. M., and E. Reiss. 1972. Multiple immunoreactive molecular forms of parathyroid hormone in human serum. Proc. Soc. Exp. Biol. Med. 140: 13931398.

22. Goldsmith, R. S., J. Furszyfer, W. J. Johnson, A. E. Fournier, G. W. Sizemore, and C. D. Arnaud. 1973. Etiology of hyperparathyroidism and bone disease during chronic hemodialysis. III. Evaluation of parathyroid suppressibility. J. Clin. Invest. 52: 173-180.

23. Silverman, R., and R. S. Yalow. 1973. Heterogeneity of parathyroid hormone: clinical and physiologic implications. J. Clin. Invest. 52: 1958-1971.

24. Fischer, J. A., U. Binswanger, and F. M. Dietrich. 1974. Human parathyroid hormone: immunological characterization of antibodies against a glandular extract and the synthetic amino-terminal fragments 1-22 and 1-34 and their use in the determination of immunoreactive hormone in human sera. J. Clin. Invest. 54: 1382-1394.

25. D'Amour, P., P. M. Huet, G. V. Segre, and M. Rosenblatt. 1979. Structural requirement for uptake and cleavage of iodinated bovine parathyroid hormone by the dog liver in vivo. Program, Abstracts, of the 61st Annual Meeting of the Endocrine Society, Anaheim, Calif. No. 172.

26. MacGregor, R. R., J. W. Hamilton, G. N. Kent, R. E. Shofstall, and D. V. Cohn. 1979. The degradation of proparathormone and parathormone by parathyroid and liver cathepsin B. J. Biol. Chem. 254: 4428-4433.

27. Barrett, A. J. 1977. Cathepsin B and other thiol proteinases. In Proteinases in Mammalian Cells and Tissues. A. J. Barrett, editor. North-Holland Publishing Co., Amsterdam. 181-208.

28. Canterbury, J. M., L. A. Bricker, G. S. Levey, R. L. Kozlovskis, E. Ruiz, J. E. Zull, and E. Reiss. 1975. Metabolism of bovine parathyroid hormone: immunochemical and biological characteristics of fragments generated by liver perfusion. J. Clin. Invest. 55: 12451253.

29. Rosenblatt, M., G. V. Segre, and J. T. Potts, Jr. 1977. Synthesis of a fragment of parathyroid hormone bPTH(28-48): an inhibitor of hormone cleavage in vivo. Biochemistry. 16: 2811-2816. 